\title{
FAKTOR RISIKO KEJADIAN KEMATIAN JANIN DALAM RAHIM (KJDR) PADA IBU HAMIL DENGAN MALARIA DI PUSKESMAS SENTANI KABUPATEN JAYAPURA
}

\author{
Ruth Yogi ${ }^{1}$, Eka Setyaning Suci ${ }^{2}$, Sri Wahyuni ${ }^{3}$ \\ ${ }^{1,2,3}$ Dosen Jurusan Kebidanan Poltekkes Kemenkes Jayapura \\ Email : ruthyogi8@gmail.com
}

\begin{abstract}
ABSTRAK
Pendahuluan. Malaria merupakan salah satu penyakit menular yang masih menjadi masalah kesehatan yang utama di Indonesia. Penyakit malaria mempunyai pengaruh yang sangat besar pada angka kesakitan dan kematian bayi, anak balita dan ibu hamil serta dapat menyebabkan penurunan produktifitas kerja. Risiko malaria akan mengakibatkan anemia 3-15\%, berat badan lahir rendah $13-70 \%$ dan kematian neonatal 3-8\%. Pengaruh Infeksi malaria pada kehamilan terhadap janin akan menyebabkan abortus, persalinan prematur, BBLR (Berat Badan Lahir Rendah, dan KJDR (Kematian Janin Dalam Rahim). Tujuan. Penelitian ini bertujuan untuk mengetahui risiko umur, paritas, suku ibu, penyakit malaria pada kehamilan terhadap kejadian Kematian Janin Dalam Rahim (KJDR) di Puskesmas Sentani. Metode. Penelitian ini menggunakan pendekatan retrospektif dengan rancangan penelitian case control. Populasi adalah seluruh ibu hamil yang mengalami KJDR dari tahun 2010-2018 di Puskesmas Sentani sejumlah 36 orang. Teknik Pengambilan Sampel dengan Teknik Total Sampling dengan jumlah sampel adalah 72 dengan perbandingan 36 kelompok kasus (yang mengalami KJDR) dan 36 kelompok Kontrol. Sumber data yang digunakan berasal dari rekam medik dari tahun 2010-2018. Analisis data uji bivariat dengan chi square, uji multivariat dengan regresi logistic berganda. Hasil. Pada Uji Bivariat didapatkan umur, paritas, dan suku bangsa bukan merupakan factor risiko terhadap kejadian KJDR dg $\mathrm{p}$ value $>0,05$. Hanya Penyakit malaria yang berisiko terhadap kejadian malaria dengan p value $0,005(<0,05)$ dan nilai OR 5,5547. Secara uji Multivariat, faktor paling berisiko terhadap kejadian KJDR adalah penyakti Malaria dengan $\mathrm{p}$ value $0,007(<0,05)$ dan nilai Exp (B) paling besar yaitu 5,043 dengan CI 1,563-16,276. Simpulan. Faktor yang paling berisiko terhadap kejadian KJDR adalah penyakit malaria.
\end{abstract}

Kata Kunci: KJDR, Hamil dengan malaria

\section{ABSTRACT}

Introduction. Malaria is an infectious disease that is still a major health problem in Indonesia. Malaria has a huge influence on the morbidity and mortality rates for infants, toddlers and pregnant women and can cause a decrease in work productivity. The risk of malaria will result in anemia 3-15\%, low birth weight 13-70\% and 3-8\% neonatal mortality. The effect of malaria infection on pregnancy on the fetus will 
cause abortion, preterm delivery, LBW (Low Birth Weight, and Intra Uterine Fetal Death (IUFD). Purpose. This study aims to determine the risk of age, parity, maternal ethnicity, malaria in pregnancy to the incidence of intrauterine fetal death (IUFD) at Sentani Health Center. Methods. This study used a retrospective approach with a case control study design. The population is all pregnant women who experienced IUFD from 2010-2018 at Sentani Public Health Center totaling 36 people. The sampling technique used was a total sampling technique with a total sample size of 72 with a comparison of 36 cases (who experienced KJDR) and 36 control groups. The data source used comes from medical records from 2010-2018. Analysis of bivariate with chi square test, and multivariate test data with multiple logistic regression. Results. In the Bivariate Test, it was found that age, parity, and ethnicity were not risk factors for the incidence of KJDR with $p$ value $>0.05$. Only malaria has a risk of malaria incidence with a p value of $0.005(<0.05)$ and an OR value of 5.5547. In the multivariate test, the mostrisky factor for the incidence of domestic violence was malaria with $p$ value 0.007 (<0.05) and the highest Exp (B) value was 5.043 with CI 1.563-16.276. Conclusion. The dominant Risk Factor of IUFD was Malaria.

Keywords: Intra Uterin Fetal Death (IUFD), Malaria in Pregnancy

\section{PENDAHULUAN}

Malaria adalah suatu penyakit infeksi akut yang disebabkan oleh infeksi Plasmodium yang menyerang sel darah merah (Febriyanti \& Suwadi, 2019). Plasmodium tersebut yang terbawa melalui gigitan nyamuk akan berkembang biak di dalam sel darah merah manusia. Penyakit malaria menyerang hampir semua kelompok umur baik perempuan maupun laki-laki. Orang yang menderita malaria ditandai dengan dengan gejala anemia, demam, menggigil, dan pembesaran limpa (Arsin, 2012).

Malaria merupakan masalah yang sifatnya sudah global hal tersebut berdasarkan pada konferensi menteri kesehatan dunia. World Malaria Report 2015 menyebutkan bahwa negara dengan iklim tropis dan subtropis menjadi wilayah endemis malaria. Negara Asia Tenggara yang termasuk wilayah endemis malaria yaitu Indonesia, Myanmar, dan Thailand. Berdasarkan komitmen global Millenium Development Goals (MDGs), Pemberantasan malaria masuk ke dalam salah satu tujuan yang harus dicapai sampai tahun 2015 (Arsin, 2012). Berakhirnya MDGs pada tahun 2015, kemudian dilanjutkan melalui Sustainable Development Goals (SDGs). Dalam tujuan ketiga SDGs, yaitu menjamin kehidupan yang sehat dan mengupayakan kesejahteraan bagi semua orang, dengan tujuan yang spesifik yaitu pemberantasan dan mengakhiri 
AIDS, tuberkulosis, dan malaria sampai dengan tahun 2030. Penyakit yang ditularkan melalui gigitan nyamuk Anopheles betina masih menjadi masalah kesehatan di beberapa wilayah Indonesia. Berdasarkan API (Annual Parasite Incidence), Indonesia bagian timur masuk dalam stratifikasi malaria yang tinggi. Tiga provinsi di wilayah timur Indonesia dengan nilai API tertinggi yaitu Provinsi Papua (42.64\%), Provinsi Papua Barat (38.44\%) dan Provinsi Nusa Tenggara Timur (16.37\%) (KEMENKES RI, 2014).

Sekitar 4,2 miliar orang (hampir separuh populasi dunia) rentan terserang malaria. Pada 2015, ditemukan 214 juta orang terinfeksi malaria dan 438.000 di antaranya meninggal. Angka kematian akibat malaria jauh lebih tinggi dibandingkan dengan ebola yang memicu kematian 4000 orang di Afrika tahun 2015 lalu (WHO, 2015).

Rencana Strategis Kementerian Kesehatan Tahun 2015-2019, dalam 5 tahun terakhir, Angka Kematian Neonatal (AKN) tetap samayakni 19/1.000 KH. Penyebab kematian disebabkan oleh Intra Uterine Fetal Death (IUFD) sebanyak 29,5\% dan Bayi Berat Lahir Rendah (BBLR) sebanyak 11,2\%. Angka kematian neonatal di Propinsi Papua masih diatas angka nasional yaitu 257 per $1000 \mathrm{KH}$, sedangkan jumlah AKI 111 per 1000 KH (Dinkes Propinsi Papua, 2017).

Angka Kesakitan Malaria (Annual Malaria Insidence (AMI)) mulai menunjukkan penurunan pada tahun 2017 yaitu sebesar 52,32\% jika dibandingkan pada tahun 2015 yaitu sebesar 54,24\%. Kabupaten Jayapura memiliki angka kejadian malaria dengan API 201,86 per 1000 penduduk yang merupakan peringkat ketiga jumlah API tertinggi se-Propinsi Papua setelah Kabupaten Keroom dan Kabupaten Mimika (Dinkes Propinsi Papua,2017).

Data dari Dinas Kesehatan Kabupaten Jayapura tahun 2018 jumlah kelahiran sebanyak 4.242 sedangkan KJDR 55 orang atau 1,29\% (Dinkes Kabupaten Jayapura, 2018).

Malaria yang terjadi pada kehamilan dapat menimbulkan berbagai keadaan patologi pada ibu hamil seperti demam, anemia, hipoglikemia, udema paru akut, gagal ginjal bahkan dapat menyebabkan kematian. Pada janin menyebabkan abortus, persalinan prematur, berat badan lahir rendah, dan kematian janin. Kelainan yang ditimbulkan ini sangat tergantung pada status imunitas, jumlah paritas dan umur ibu 
hamil. Di daerah endemisitas tinggi, dimana penduduknya sudah mempunyai imunitas terhadap malaria, jarang terjadi malaria berat dan kematian. Klinis yang ditimbulkan dan derajat parasitemia juga akan lebih berat pada ibu hamil primigravida dan berumur muda (Rusjdi, 2012).

Terjadinya infeksi malaria disebabkan oleh faktor individu dan faktor lingkungan. Faktor individu yaitu usia, jenis kelamin, genetik, kehamilan, status gizi, aktivitas di luar rumah pada malam hari, dan faktor risiko lingkungan yaitu perumahan, keadaan musim, sosial ekonomi, dan lain-lain. Faktor prediktor yang mempengaruhi terjadinya BBLR, Abortus dan KJDR secara umum bersifat multifaktoral, sehingga kadang mengalami kesulitan untuk melakukan tindakan pencegahan.

Banyak faktor yang berhubungan dengan kejadian malaria. Secara teoritis dan beberapa penelitian bahwa, faktor lingkungan, perilaku, pelayanan kesehatan dan genetik merupakan determinan yang berhubungan erat dengan risiko penduduk terserang malaria(Sutarto dan Cania, 2017).

Frekuensi KJDR paling banyak terjadi pada ibu preterm, usia 20-35 tahun, multipara, IMT normal, ibu yang tidak berpenyakit, tidak gemeli, tidak ada prolapsus tali pusat, dan tidak mengalami solusio plasenta (Mardania, Sawitri, and Fransiska 2019).

Suku bangsa adalah suatu golongan manusia yang mengidentifikasi dirinya dengan sesama berdasarkan garis keturunan yang dianggap sama dengan merujuk ciri khas seperti: budaya, bangsa, bahasa, agama dan perilaku. Suku bangsa adalah golongan sosial yang dibedakan dari golongan-golongan sosial lainnya, karena mempunyai ciri-ciri yang paling mendasar dan umum yang berkaitan dengan asal usul, tempat asal, serta kebudayaannya (Hidayah, 2015).

\section{METODE}

Penelitian ini menggunakan pendekatan retrospektif dengan rancangan penelitian case control. Populasi adalah seluruh ibu hamil yang mengalami Kematian Janin dalam Rahim (KJDR) dari tahun 2010-2018 di Puskesmas Sentani sejumlah 36 orang. Teknik Pengambilan Sampel dengan Teknik Total Sampling dengan jumlah sampel adalah 72 dengan perbandingan 36 kelompok kasus (yang mengalami KJDR) dan 36 kelompok Kontrol. Jumlah populasi dalam penelitian ini adalah kasus, KJDR: 36 
kasus. Sampel kasus yang digunakan adalah bayi yang lahir KJDR dengan riwayat ibu yang menderita malaria sedangkan kasus control adalah bayi bukan, KJDR dari ibu yang tidak menderita penyakit malaria. Data menderita penyakit malaria atau tidak tercantum di dalam rekam medis dan buku KIA masing -masing pasien. Sumber data yang digunakan berasal dari rekam medik dari tahun 2010-2018 Metode pengumpulan data dari rekam medik pasien dengan tetap menjaga kerahasiaan data. Analisis univariat Dilakukan terhadap tiap variabel penelitian untuk melihat distribusi frekuensi dari masing-masing variable. Analisis bivariate pada penelitian ini menggunakan uji Chi square untuk menguji hipotesis penelitian antar variabel independen/bebas yaitu umur ibu, paritas, suku/ras, malaria terhadap variabel dependen/terikat yaitu, KJDR. Uji analisis Multivariat menggunakan uji regresi logistic berganda.

\section{HASIL}

\section{Analisis Univariat}

1. Umur

Umur berisiko jika $<20$ tahun atau $>35$ tahun. Umur tidak berisiko jika 20-35 tahun. Perbandingan perbedaan proporsi kejadian KJDR antara responden dengan kategorik umur berisiko dan umur tidak berisiko pada kelompok kontrol dan kelompok kasus yaitu sebagaian besar 27 responden (75\%) umur tidak berisiko dan tidak mengalami kejadian KJDR (kelompok kontrol). Sedangkan responden yang memiliki umur berisiko pada kehamilan sebanyak 7 responden $(19,4 \%)$ mengalami kejadian KJDR (kelompok kasus).

\section{Paritas}

Paritas berisiko adalah jika melahirkan lebih dari 5 kali, paritas tidak berisiko adalah jika melahirkan kurang dari 5 kali. Perbandingan perbedaan proporsi kejadian KJDR antara responden dengan kategorik paritas berisiko dan paritas tidak berisiko pada kelompok kontrol dan kelompok kasus yaitu sebagaian besar 27 responden (75\%) paritas tidak berisiko dan tidak mengalami kejadian KJDR (kelompok kontrol). Sedangkan responden yang memiliki paritas berisiko pada kehamilan sebagian kecil sebanyak 7 responden $(19,4 \%)$. mengalami kejadian KJDR (kelompok kasus). 


\section{Suku}

Perbandingan perbedaan proporsi kejadian KJDR antara responden dengan kategorik suku Papua dan suku Non Papua pada kelompok kontrol dan kelompok kasus yaitu sebagaian kecil sebanyak 16 responden (44\%) suku Non Papua tidak mengalami kejadian KJDR (kelompok kontrol). Sedangkan responden suku Papua sebagian besar 26 responden (72,2\%) mengalami kejadian KJDR (kelompok kasus).

\section{Riwayat Malaria}

Perbandingan perbedaan proporsi kejadian KJDR antara responden yang tidak memiliki riwayat penyakit malaria pada kehamilan dan responden yang memiliki riwayat penyakit malaria pada kehamilan pada kelompok kontrol dan kelompok kasus yaitu sebagaian besar $24(60 \%)$ responden yang tidak memiliki riwayat penyakit malaria tidak mengalami kejadian KJDR (kelompok kontrol). Sedangkan responden yang memiliki riwayat penyakit malaria pada kehamilan sebagian besar 11 (78,6\%) mengalami kejadian KJDR (kelompok kasus).

\section{Analisis Bivariat}

Analisis bivariat dilakukan untuk mengetahui hubungan satu variabel bebas dengan satu variabel terikat, yang dilakukan dengan uji statistik Chi-0,05). Jika $p$ value lebih kecil dari $\alpha(\mathrm{p}<0,05)$, artinya terdapat hubungan yang bermakna Square. Derajat kepercayaan yang digunakan adalah $95 \%(\alpha=$ (signifikan) dari kedua variabel yang diteliti. Bila $p$-value lebih besar dari $\alpha(\mathrm{p}>0,05)$, artinya tidak terdapat hubungan bermakna antara kedua variabel yang diteliti.

1. Pengaruh Umur terhadap kejadian KJDR

Pada uji Chi square variabel diperoleh p-value 0,777 ( $p$-value $>0,05)$ didapatkan $\mathrm{OR}=1,381$. Sehingga dapat disimpulkan bahwa tidak ada pengaruh antara umur terhadap kejadian KJDR.

2. Pengaruh Paritas terhadap kejadian KJDR

Pada uji Chi square variabel diperoleh p-value 0,285 ( $p$-value $>0,05)$ didapatkan $\mathrm{OR}=2,071$. Sehingga dapat disimpulkan bahwa tidak ada pengaruh antara paritas terhadap kejadian KJDR. 


\section{Pengaruh Suku terhadap kejadian KJDR}

Pada uji Chi square variabel diperoleh p-value 0,220 (p-value $>0,05)$ didapatkan

$\mathrm{OR}=0,481$. Sehingga dapat disimpulkan bahwa tidak ada pengaruh antara suku terhadap kejadian KJDR.

4. Pengaruh Riwayat Penyakit Malaria terhadap kejadian KJDR

Pada uji Chi square variabel riwayat penyakit malaria pada kehamilan diperoleh $p$-value 0,005 ( $p$-value $<0,05)$ didapatkan $\mathrm{OR}=5,5$. Sehingga dapat disimpulkan bahwa ada pengaruh antara riwayat penyakit malaria pada kehamilan terhadap kejadian KJDR. Riwayat penyakit malaria pada kehamilan mempunyai peluang lebih tinggi terhadap kejadian KJDR. Interval kepercayaan (CI) batas bawah 1,323 dan batas atas 22,862 sehingga dikatakan bahwa makin kuat dugaan jika terjadi penyakit malaria pada kehamilan merupakan faktor risiko terjadinya KJDR. Artinya risiko terjadinya KJDR pada ibu hamil yang memiliki riwayat penyakit malaria pada kehamilan 5,5 kali lebih besar dibandingkan yang tidak menderita malaria pada kehamilan.

Tabel.1. Pengaruh Umur, paritas, suku dan riwayat penyakit malaria terhadap kejadian KJDR

\begin{tabular}{lcccc}
\hline \multicolumn{1}{c}{ Variabel } & Pearson Chi- & Odds ratio & \multicolumn{2}{c}{$95 \%$ Confidence Interval } \\
& Square & (OR) & Lower & Lower \\
\hline Umur & 0,777 & 1,381 & 0,451 & 4,225 \\
Paritas & 0,285 & 2,071 & 0,705 & 6,086 \\
Suku & 0,220 & 0,481 & 0,180 & 1,283 \\
Riwayat Penyakit Malaria & 0,005 & 5,5547 & 1,758 & 17,503 \\
\hline
\end{tabular}

\section{Analisis Multivariat}

Analisis multivariat ditujukan untuk mengestimasi hubungan antara umur, paritas, suku dan riwayat penyakit malaria terhadap kejadian KJDR. Analisis yang digunakan adalah regresi logistik berganda dengan tingkat kepercayaan 95\% (95\% CI).

1. Regresi logistik multivariat subvariabel independen umur, paritas, suku, riwayat penyakit malaria terhadap kejadian KJDR

a. Pemilihan Variabel Kandidat Pemodelan

Tabel 2. Hasil Pemilihan Variabel Kandidat Yang Akan Diikutkan Dalam Analisis Multivariat 


\begin{tabular}{clccc}
\hline No & & Variabel & Sig. & Keterangan \\
\hline 1 & Umur & 0,775 & Bukan Kandidat \\
2 & Paritas & 0,285 & Bukan Kandidat \\
3 & Suku & 0,220 & Kandidat \\
4 & Riwayat Penyakit Malaria & 0,002 & Kandidat \\
\hline
\end{tabular}

Bila hasil analisis bivariat antara variabel independen dan dependen menghasilkan $p$-value $<0,25$, maka variabel independen tersebut dimasukkan ke tahap analisis multivariat.

Dari hasil Uji Regresi Logistik Berganda menurut tabel 3 didapatkan bahwa factor yang paling berisiko terhadap kejadian KJDR adalah Malaria dengan $\mathrm{p}$ value 0,007 $(<0,05)$ dan nilai Exp (B) paling besar yaitu 5,043 dengan CI $1,563-16,276$.

Tabel 3. Hasil Uji Multivariat

\begin{tabular}{|c|c|c|c|c|c|}
\hline No & & Variabel & Sig. & $\operatorname{Exp}(B)$ & C.I \\
\hline 1 & Suku & & 0,438 & 0,660 & $0,231-1,886$ \\
\hline 2 & Malaria & & 0,007 & 5,043 & $1,563-16,276$ \\
\hline
\end{tabular}

\section{PEMBAHASAN}

1. Umur

Berdasarkan penelitian ini didapatkan distribusi responden sebagian besar umur tidak berisiko pada kelompok control dengan 27 responden $(75 \%)$ namun ada kelompok kasus 7 responden (19,4\%). Pada uji bivariate di dapatkan Pada uji Chi square variabel diperoleh $p$-value 0,777 ( $p$-value $>0,05)$ didapatkan $\mathrm{OR}=1,381$. Sehingga dapat disimpulkan bahwa tidak ada pengaruh antara umur terhadap kejadian KJDR. Penelitian ini tidak sejalan dengan penelitian yang dilakukan oleh Nurfadila (2013) mengatakan bahwa ada hubungan antara umur ibu dengan kejadian KJDR dengan nilai $\rho(0,007)$.

Namun Penelitian yang di lakukan oleh Gerungan (2016) hubungan umur ibu dengan kejadian Intra Uterin Fetal Death (IUFD /KJDR) didapatkan nilai $\rho$ value = $0,594(\rho>0,05)$ artinya tidak terdapat hubungan yang signifikan antara umur ibu dengan kejadian IUFD. Hasil keputusan ini tidak sesuai dengan teori yang mengatakan bahwa umur ibu yang berisiko $(<20$ dan $>35$ tahun) adalah salah satu faktor penyebab terjadinya IUFD. Dengan demikian asumsi dari peneliti bahwa 
umur ibu tidak ada hubungan dengan kejadian IUFD karena ada faktor-faktor penyebab lain seperti faktor maternal, fetal dan plasenta (Gerungan,2016).

Namun ada factor lain juga sangat berperan dalam kejadian IUFD/KJDR yaitu faktor maternal, fetal dan plasental merupakan penyebab kejadian IUFD. Faktor maternal yaitu, umur ibu, umur kehamilan dan penyakit yg diderita oleh ibu seperti preeklampsia, eklampsia, diabetes mellitus, dan KPD. Faktor fetal yaitu hamil kembar, kelainan kongenital. Faktor plasental yaitu kelainan tali pusat, lilitan tali pusat, solutio plasenta dan plasenta previa (Gerungan,2016).

Sedangkan pada ibu dengan riwayat malaria yaitu sebagaian besar $24(60 \%)$ responden yang tidak memiliki riwayat penyakit malaria tidak mengalami kejadian KJDR (kelompok kontrol). Sedangkan responden yang memiliki riwayat penyakit malaria pada kehamilan sebagian besar 11 (78,6\%) mengalami kejadian KJDR (kelompok kasus). Hal ini tidak bisa diabaikan sebab terdapat 7 responden dengan umur berisiko terkena KJDR namun setelah di uji dengan regresi logistic berganda bahwa umur ibu tdk ada pengaruh terhadap kejadian KJDR. Menurut Nugroho penyebab kematian janin bisa disebabkan oleh penyakit lain seperti DM dalam kehamilan, trauma, lilitan tali pusat ataupun kekurangan nutrisi.

2. Paritas

Sebagaian besar 27 responden (75\%) paritas tidak berisiko dan tidak mengalami kejadian KJDR (kelompok kontrol). Sedangkan responden yang memiliki paritas berisiko pada kehamilan sebagian kecil sebanyak 7 responden (19,4\%) mengalami kejadian KJDR (kelompok kasus).

Pada uji bivariate dengan menggunakan uji Chi square diperoleh p-value 0,285 $(p$-value $>0,05)$ didapatkan $\mathrm{OR}=2,071$. Sehingga dapat disimpulkan bahwa tidak ada pengaruh antara paritas terhadap kejadian KJDR. Namun tidak dapat diabaikan bahwa ada sebagian kecil ibu dengan jumlah paritas berisiko terkena KJDR. Dan setelah dilakukan uji multivariate dengan nilai $\mathrm{P}$ value $>0,25$ sehingga tidak terdapat pangaruh antara jumlah paritas ibu dengan kejadian KJDR. Hal ini di perkuat oleh penelitian Gerungan (2013) bahwa ada penyakit lain selain penyakit malaria 
Penelitian ini tidak sejalan dengan Gerungan 2013. Di ketahui bahwa ada hubungan antara paritas dengan kejadian KJDR dengan nilai $\rho(0,001)$.

Penelitian berbeda (Gerungan,2016) mengatakan bahwa Ada pengaruh signifikan antara Penyakit yang menyertai kehamilan terhadap kejadian IUFD, dengan $\mathrm{p}=0.000$, dan adanya penyakit yang menyertai kehamilan berpotensi menyebabkan IUFD 7 kali.

Sesuai hasil penelitian tertinggi adalah hipertensi $47 \%$ dan malaria yang mengakibatkan anemia sebanyak 21\%. Seperti yang kita tahu bahwa malaria dapat mengakibatkan anemia karena parasite malaria banyak menyerang sel darah merah. Akibat anemia, supply oksigen menjadi tidak adekuat yang berdampak pada kemampuan metabolism tubuh, yang dapat berdampak pada hypoxia pada jaringan placenta sehingga menimbulkan IUFD (Sulansi, 2013).

3. Suku

Sebagaian kecil sebanyak 16 responden (44\%) suku Non Papua tidak mengalami kejadian KJDR (kelompok kontrol). Sedangkan responden suku Papua sebagian besar 26 responden (72,2\%) mengalami kejadian KJDR (kelompok kasus).

Pada uji Chi square variabel diperoleh p-value 0,220 (p-value $>0,05)$ didapatkan $\mathrm{OR}=0,481$. Sehingga dapat disimpulkan bahwa tidak ada pengaruh antara suku terhadap kejadian KJDR.

Hal ini sejalan dengan hasil penelitian sebelumnya memperlihatkan proporsi jumlah penderita malaria pada Suku Anak Dalam maupun suku lainnya tidak begitu berbeda. Hasil uji statistik (Mann- Whitney Test), menunjukkan tidak terdapat perbedaan antara Suku Anak Dalam maupun suku lainnya terhadap kasus yang ditemukan positif malaria ( $\mathrm{p}>0,05)$ (Sitorus $\mathrm{dkk}, 2012)$.

\section{Penyakit Malaria}

Pada uji Chi square variabel riwayat penyakit malaria pada kehamilan diperoleh $p$-value 0,005 ( $p$-value $<0,05)$ didapatkan $\mathrm{OR}=5,5$. Sehingga dapat disimpulkan bahwa ada pengaruh antara riwayat penyakit malaria pada kehamilan terhadap kejadian KJDR. Riwayat penyakit malaria pada kehamilan mempunyai peluang lebih tinggi terhadap kejadian KJDR. Interval kepercayaan (CI) batas 
bawah 1,323 dan batas atas 22,862 sehingga dikatakan bahwa makin kuat dugaan jika terjadi penyakit malaria pada kehamilan merupakan faktor risiko terjadinya KJDR. Artinya risiko terjadinya KJDR pada ibu hamil yang memiliki riwayat penyakit malaria pada kehamilan 5,5 kali lebih besar dibandingkan yang tidak menderita malaria pada kehamilan.

Dari hasil Uji Multivariat factor yang paling berisiko terhadap kejadian KJDR adalah penyakit Malaria dengan p value 0,007 $(0,05)$ dan nilai Exp (B) paling besar yaitu 5,043 dengan CI 1,563-16,276.

Hal ini sejalan dengan penelitian sebelumnya yang menyebutkan ada Pengaruh Penyakit malaria yang menyertai kehamilan terhadap kejadian IUFD, terdapat pengaruh signifikan terhadap kejadian IUFD dimana hasil uji regresi logistic $\mathrm{p}=$ 0.000. Sesuai hasil penelitian tertinggi adalah hipertensi $47 \%$ dan malaria yang mengakibatkan anemia sebanyak 21\% (Sulansi, 2013).

Kekebalan terhadap malaria lebih banyak ditentukan dari tingkat transmisi malaria tempat wanita hamil tinggal / berasal, yang dibagi menjadi 2 golongan besar yaitu Stable transmission / transmisi stabil, atau endemik dan Unstable transmission / transmisi tidak stabil, epidemik atau non-endemik . Orang-orang yang berada di daerah transmisi stabil akan terus- menerus terpapar malaria karena sering menerima gigitan nyamuk infektif setiap bulannya sehingga imunitas yang terbentuk cukup signifikan untuk bertahan dari serangan parasit malaria. Orang yang berada di daerah Unstable transmission, epidemik atau non-endemik jarang terpapar malaria dan hanya menerima rata-rata kurang dari 1 gigitan nyamuk infektif / tahun. Wanita hamil yang berada di daerah tersebut akan mengalami peningkatan resiko penyakit maternal berat, kematian janin, kelahiran prematur dan kematian perinatal. Ibu hamil yang menderita malaria berat di daerah ini memiliki risiko kemungkinan fatal lebih dari 10 kali dibandingkan ibu tidak hamil yang menderita malaria berat di daerah yang sama (Rusjdi, 2012).

\section{SIMPULAN}

Pada Uji Bivariat didapatkan umur, paritas, dan suku bangsa bukan merupakan factor risiko terhadap kejadian KJDR dg p value $>0,05$. Hanya Penyakit malaria yang 
berisiko terhadap kejadian malaria dengan p value $0,005(<0,05)$ dan nilai OR 5,5547.

Secara uji Multivariat, faktor paling berisiko terhadap kejadian KJDR adalah penyakti Malaria dengan $\mathrm{p}$ value $0,007(<0,05)$ dan nilai Exp (B) paling besar yaitu 5,043 dengan CI 1,563-16,276.

\section{DAFTAR PUSTAKA}

Arsin, A. A. (2012). Malaria di Indonesia tinjauan aspek epidemiologi. Makassar : Masagena.

Badan Pusat Statistika. (2014). Provinsi Papua dalam angka 2014. Papua: BPS Papua.

Dinkes Kabupaten Jayapura. 2017. Profil Kesehatan Kabupaten Jayapura tahun 2017. Jayapura : Dinkes Kab Jayapura

Dinkes Provinsi Papua. 2018. Profil Kesehatan Provinsi Papua tahun 2018. Jayapura : Dinkes Provinsi Papua.

Gerungan Elvi N, 2016, Faktor-Faktor Yang Berhubungan Dengan Kejadian IUFD Di RSUP Prof. Dr. R. D. Kandou Manado, Jurnal Ilmiah Bidan, ISSN : 23391731 Volume 4 Nomor 1. Januari - Juni 2016

KEMENKES RI. 2014. Riset kesehatan dasar dalam angka (RISKESDAS 2013). Jakarta : Kemenkes RI.

Nurfadila, Nurfadila(2013) Faktor-faktor yang Berhubungan dengan Kejadian Kematian Janin dalam Rahim (KJDR) di Rumah Sakit Khusus Daerah Ibu dan Anak Siti Fatimah Makassar. Undergraduate (S1) thesis, Universitas Islam Negeri Alauddin Makassar.

Mardania, Nursaci, Endang Sawitri, and Novia Fransiska. 2019. "Gambaran Faktor Risiko Intrauterine Fetal Death (Iufd)." Jurnal Medika Karya Ilmiah Kesehatan 4(1): 117-29.

Rusjdi, Selfi Renita. 2012. "Malaria Pada Masa Kehamilan.” Majalah Kedokteran Andalas 36(2): 173.

Sitorus H, Oktarina, Lasbudi P. Ambarita. 2012. "Malaria Pada Anak Di Desa Pagar Desa (Pemukiman Suku Anak Dalam) Di Kabupaten Musi Banyuasin Propinsi Sumatera Selatan." Media Penelitian dan Pengembangan Kesehatan 21(1 Mar): $10-17$.

Sulansi, Hendrikus Mbira, 2013, Faktor-Faktor Yang Mempengaruhi Kejadian Iufd Di Rsud Ende, Jurnal Info Kesehatan, Vol 11 Nomor 2 Desember 2013 
Sutarto, and Eka Cania. 2017. "Faktor Lingkungan, Perilaku Dan Penyakit Malaria." Agromed Unila 4(1): 271-78.

WHO.2014. World Malaria Report 2014. Geneva : WHO. 